\title{
$34 \sqrt[4]{65}$ MASTER
}

DOE/NASA CONTRACTOR REPORT

DOE/NASA CR-150856

December 1978

\section{SOLAR HOT WATER SYSTEM INSTALLED AT ANDERSON,} SOUTH CAROLINA

Prepared from documents furnished by

Solar Designs

4 Ardmore Drive

Taylors, South Carolina 29687

Under Contract DOE 77-G-01-1663

Monitored by the

National Aeronautics and Space Administration

George C. Marshall Space Flight Center, Alabama 35812

For the U. S. Department of Energy
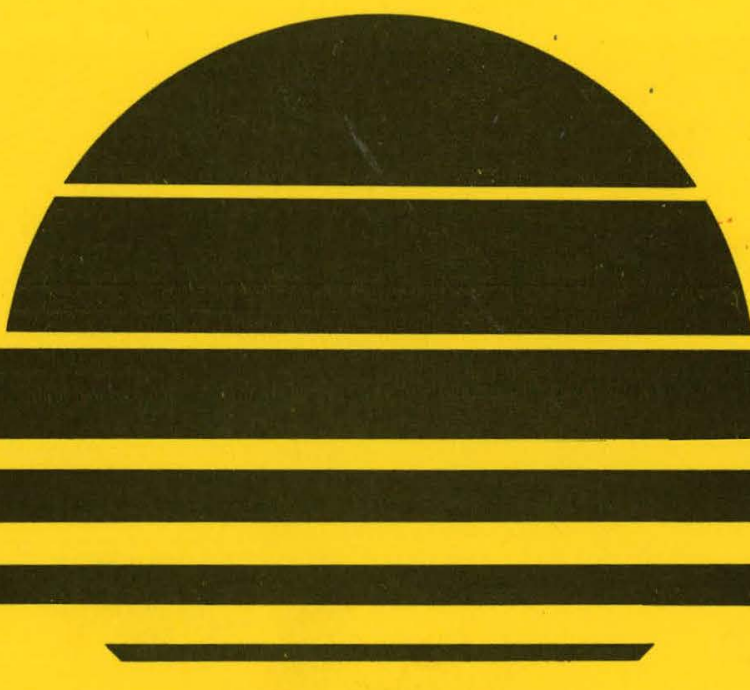

\section{U.S. Department of Energy}




\section{DISCLAIMER}

This report was prepared as an account of work sponsored by an agency of the United States Government. Neither the United States Government nor any agency Thereof, nor any of their employees, makes any warranty, express or implied, or assumes any legal liability or responsibility for the accuracy, completeness, or usefulness of any information, apparatus, product, or process disclosed, or represents that its use would not infringe privately owned rights. Reference herein to any specific commercial product, process, or service by trade name, trademark, manufacturer, or otherwise does not necessarily constitute or imply its endorsement, recommendation, or favoring by the United States Government or any agency thereof. The views and opinions of authors expressed herein do not necessarily state or reflect those of the United States Government or any agency thereof. 


\section{DISCLAIMER}

Portions of this document may be illegible in electronic image products. Images are produced from the best available original document. 
NOTICE

This report was prepared to document work sponsored by the UnIted States Government. Nelther the United States nor 1ts agents the United States Departmant of Energy, the United States National Aeronautics and Space Adminfetration, nor any federsl employees, nor any of their contractors, sutcortractors or their employees, make any warranty, express or 1niflit, or assume any legal 11ab1lity or responsibllity for the scculacy, completeness, or usefulness of any information, apparatus, product or process disclosed, or represent that 1ts use would not infringe privately owned rights. 
THIS PAGE

\section{WAS INTENTIONALLY LEFT BLANK}




\section{TABLE OF CONTENTS}

I. Key Word Abstract

II. Introduction

1

III. Design Philosophy

A. Collectors 2

B. Description of Solar Collectors 2

C. Storage System 4

D. Heat Transfer Fluid 5

E. Heat Exchanger

F. Pump and Controls 5

G. General Comments : 5

IV. Picture of Final Installation 6

V. Operation of the System. 8

VI. Problems Encountered and Solutions 8

VII. Successful Components $\quad 8$

Appendix A - Solar Hot Water Plant Drawing 9

Appendix B - Verification and Acceptance 11

Appendix C - Operātor's Instructions and Malntenance Manual 14 


\author{
Application \\ System Type \\ Collector Type \\ Collector Manufacture \\ Collector Area \\ Storage Capacity \\ Hot Water Load \\ BTU's Produced \\ Building Owner \\ Solar System Designer \\ Contractor (Installer)
}

\author{
Service Hot Water \\ Active Hydronic \\ Flat Plate, Liquid \\ Solar Energy Products, Inc. \\ 750 Square Feet \\ 1, 000 gallons, fiberglass \\ 4. $65 \times 10^{8} \mathrm{BTU} /$ Year \\ $2.0 \times 10^{8} \mathrm{BTU} /$ Year \\ Days Inn of America, Inc: \\ Mavis Q. Coley, Jr. \\ Georgia Carolina Heating and \\ Air Conditioning, North Augusta, \\ South Carolina
}

\section{INTRODUCTION}

Days Inn of America retained Solar Designs of Taylors, South Carolina and Sydney Carter AIA of Augusta, Georgia to prepare a submittal in response to the "Hot Water Initiative for Hotel/Motel Installation PON EG-77-N-03-1450." The proposal was to retrofit the company's Anderson, South Carolina property, a low rise two story 114 room motel, with 750 square feet of flat plate solar collector to provide a portion of the energy required for service hot water. The system was designed to provide $40 \%$ of the total demand.

\section{DESIGN PHILOSOPHY}

The Anderson, South Carolina property was chosen for this project because the existing system, three $54 \mathrm{KW}$ electric boilers ( 350 gallons each), were deemed to be the largest energy cost at the location; many other Days Inns are equipped with natural gas hot water heaters. The system dem and was estimated on previous occupancy records consumption of 25 gallons per day for each room and a water main source temperature of $55^{\circ} \mathrm{F}$. The demand was estimated to be $4.65^{\circ} \times 10^{8} \mathrm{BTU} /$ Year. Solar Designs chose a simple drain down system to provide $40 \%$ of the load or about $2 \times 10^{8}$ BTU/year. The system consists of one row of five collectors and two rows of ten collectors. Ball valves were installed to regulate flow. An infrared scanning thermometer was used to determine plate temperature, and the flow rate was divided to provide equal exit temperatures from each bank of collectors.

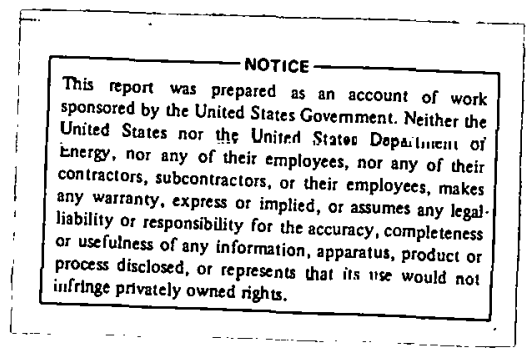




\section{A. Collectors}

The collectors chosen for this project were manufactured by Solar Energy Products, Inc. Model CU-30 WW with side outlets was decided on primarily for its ease of installation. Since the collectors were supplied with mounting hardware designed for $130 \mathrm{mile}$ per hour wind loading, no elaborate support frames were necessary along with their attendent cost. Also these collectors have $1^{\prime \prime}$ internal manifolds making external manifolds: unnecessary. The collectors were coupled together with copper unions; The $4^{\prime} \times 8^{\prime}$ collectors were mounted on the flat roof facing due south at a $35^{\circ}$ tilt. A fail-safe, self-draining system was designed to facilitate installation.

The thermal performance curve (Ashrae 93-77) has a slope of 1.00 and an intercept of .72. F-Chart computer runs indicated about $40 \%$ of the load could be supplied by the system. Also panel performance data was used to back up these calculations.

\section{B. Description - Collector Panel}

Gulf Thermal collectors (see Figure 1) have been designed to meet all known United States' codes as well as to meet all criteria as required by:

"Interim Performance Criteria for Solar Heating and Combined Heating/Cooling Systems and Dwellings" (HUD Jan 1, 1975)

"Interim Performance Criteria of Commercial Solar Heating and Combined Heating/Cooling Systems and Facilities"

(NASA 98M-10001 Feb 28, 1975)

Size overall $98.5^{\prime \prime} \times 48.5^{\prime \prime} \times 2.57^{\prime \prime}$

Weight Dry - 176\# $(3 / 16 " 1-202 \#)(7 / 32 " \prime-218 \#)$

Fluid capacity .9 gallon (7.5\#)

Framewall Specially designed aluminum extrusion. When supported at four points, panel will deflect less than one-half inch under evenly distributed load of 100 lhs, per square foot (2, 400.1bs total).

Backplate $\quad .032$ mils alumimumo

Finish $\quad . \quad$ Standard - Anodized

Option - Acrylic finish in color on special order (minimum 10 collectors) 


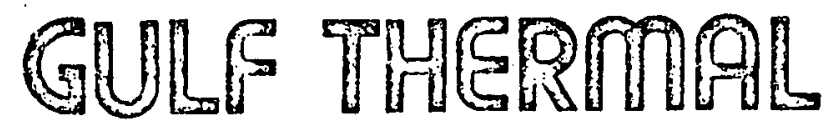
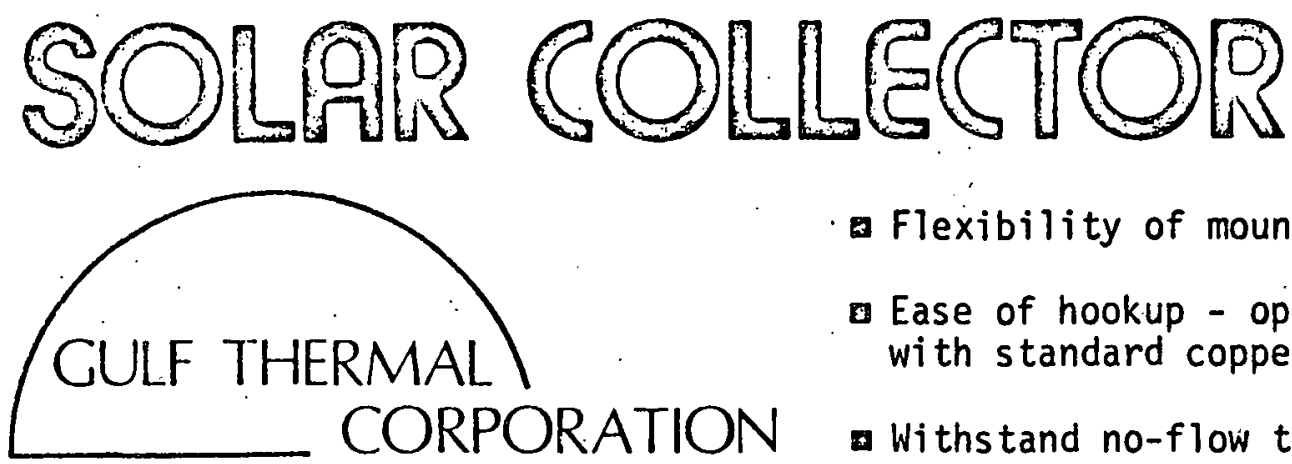

- Flexibility of mounting - fixed or adjustable

a Ease of hookup - open and closed systems compatible with standard copper plumbing components and practices

- Withstand no-flow temperatures to $300^{\circ} \mathrm{F}$.

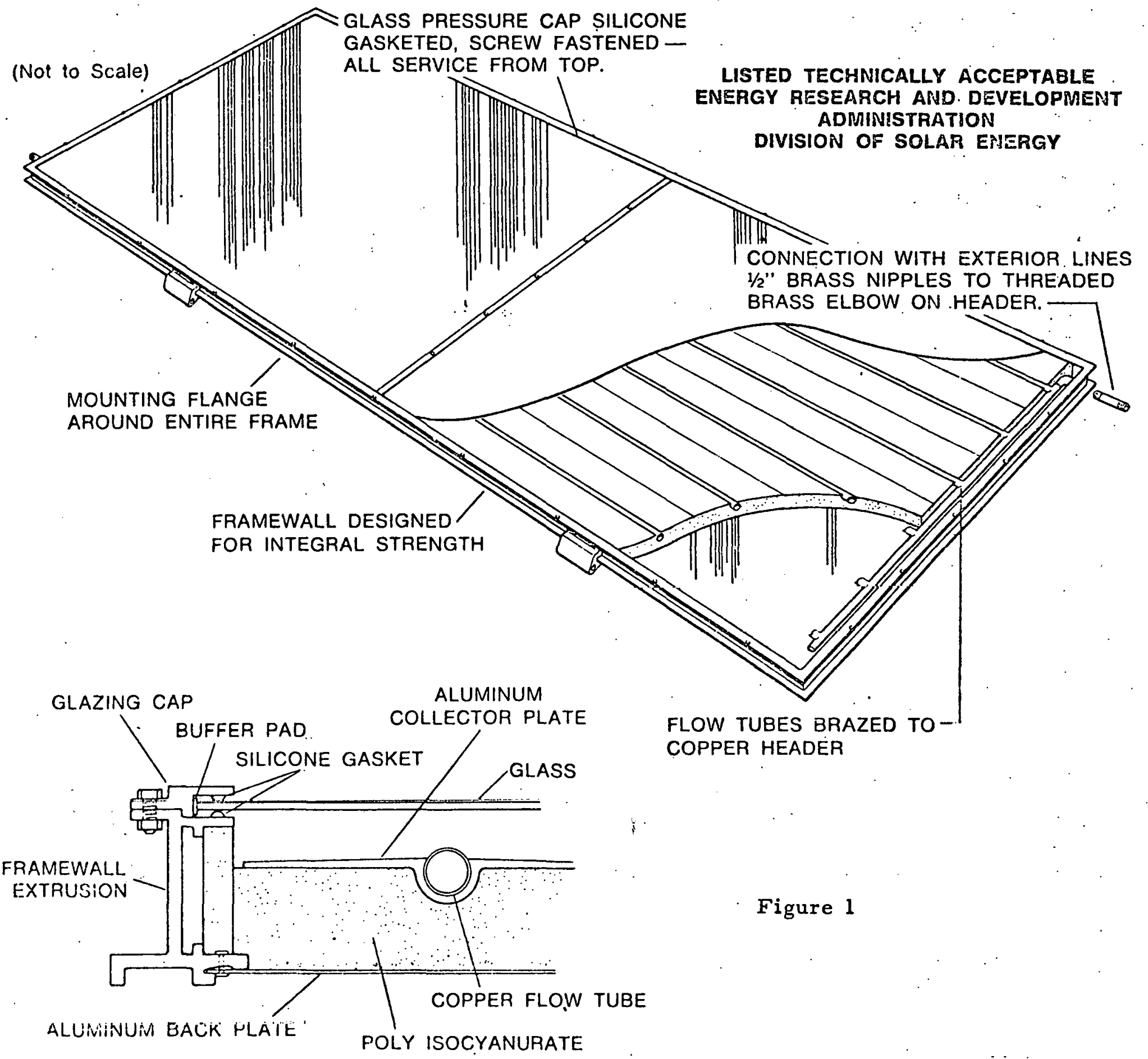


Insulation Isocyanurate foam board - 1-1/4" routed to receive flow tube pattern. Thermal conductivity - .09 BTU/HR $\mathrm{FT}^{2}$ IN. F.

Glass Standard - - 1/8" tempered or annealed low iron. Three lights.

Option -- Water white 3/16" tempered. Single light.

Both $1 / 8$ " three light and 3/16" single light designed to withstand winds to $150 \mathrm{MPH}$ with breakage probability one light per 1,000 .

Gasket - - Silicone, bonded to framewall and caps.

Absorber Plate Effective collection area: 29.65 FT. ${ }^{2}$

Materials Plate consists of $1 / 2^{\prime \prime}$ copper flow tubes mechanically expanded into extruded aluminum wings for superior thermal conductivity. Flow tubes brazed to $3 / 4^{\prime \prime}$ headers.

Treatment After testing, assembled plate is chemically treated prior to coating with absorber surface.

Coating

Flat black. Solar absorptivity .98

Emiesivity $\quad .89$

Flow characteristics: $.05 \mathrm{Ft}$. head at $.75 \mathrm{GPM}$ flow rate

Freeze protection:' Absorber plate is designed to allow fluid drainage.

Mounting (Optional) "Hinges" and roof mounts allow great flexibility in mounting collectors either in fixed or adjustable configurationo:

C. Storage System

A 1, 000 gallon fiberglass tank was located in the existing equipment room adjacent to the electric hot water heaters. The fiberglass tank was chosen to eliminate corrosion problems. Tank location was dictated by (1) ease of installation, (2) access (for routine maintenance), (3) to eliminate common problems encountered with underground storage (ground water). The tank operates at atmospheric pressure and has an upper operating limit of $200^{\circ} \mathrm{F}$. The tank is protected from high temperatures by upper limit sensors on the controller. The tank is insulated with 6 inches of ordinary fiberglass installation ( $\mathrm{U}-$ Value $=.052 \mathrm{BTU} / \mathrm{Hr} .-\mathrm{ft}^{2} \mathrm{O} \mathrm{F}$. 


\section{Heat Transfer Fluid}

City water (potable) is the only heat transfer fluid. There are no heat exchangers between the storage tank and collector loop. The collectors are protected from freezing by a simple drain-down technique. The system drains as follows: When the controller shuts the pump down, three air vent valves (one on each collector bank) open and allow air to enter the system at the highest point. The water then drains back into the storage tank. The system is fail-safe in that should the air vent valves fail, the collector discharge line is located above water level in the storage tank.

\section{E. Heat Exchanger}

Usable heat is transferred to the existing hot water heaters via

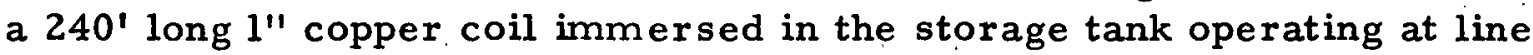
pressure. The coil is located near the surface of the water in the storage tank. This facilitates natural convection currents which provide good heat transfer without the added cost of an external heat exchanger and pumps.

\section{F. Pump and Controls}

The collector pump is an ordinary hot water circulating pump sized to provide $0.022 \mathrm{gpm} / \mathrm{ft}^{2}$. The pump is controlled by a differential controller of the usual design.

\section{G. General Comments}

Good practice for solar installations was adhered to throughout by the installing contractor. All solar system lines are insulated and protected by paint from UV radiation. All system lines were very carefully installed with slopes to facilitate complete drainage. 
IV. PICTURE OF FINAL INSTALLATION

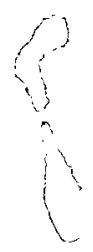




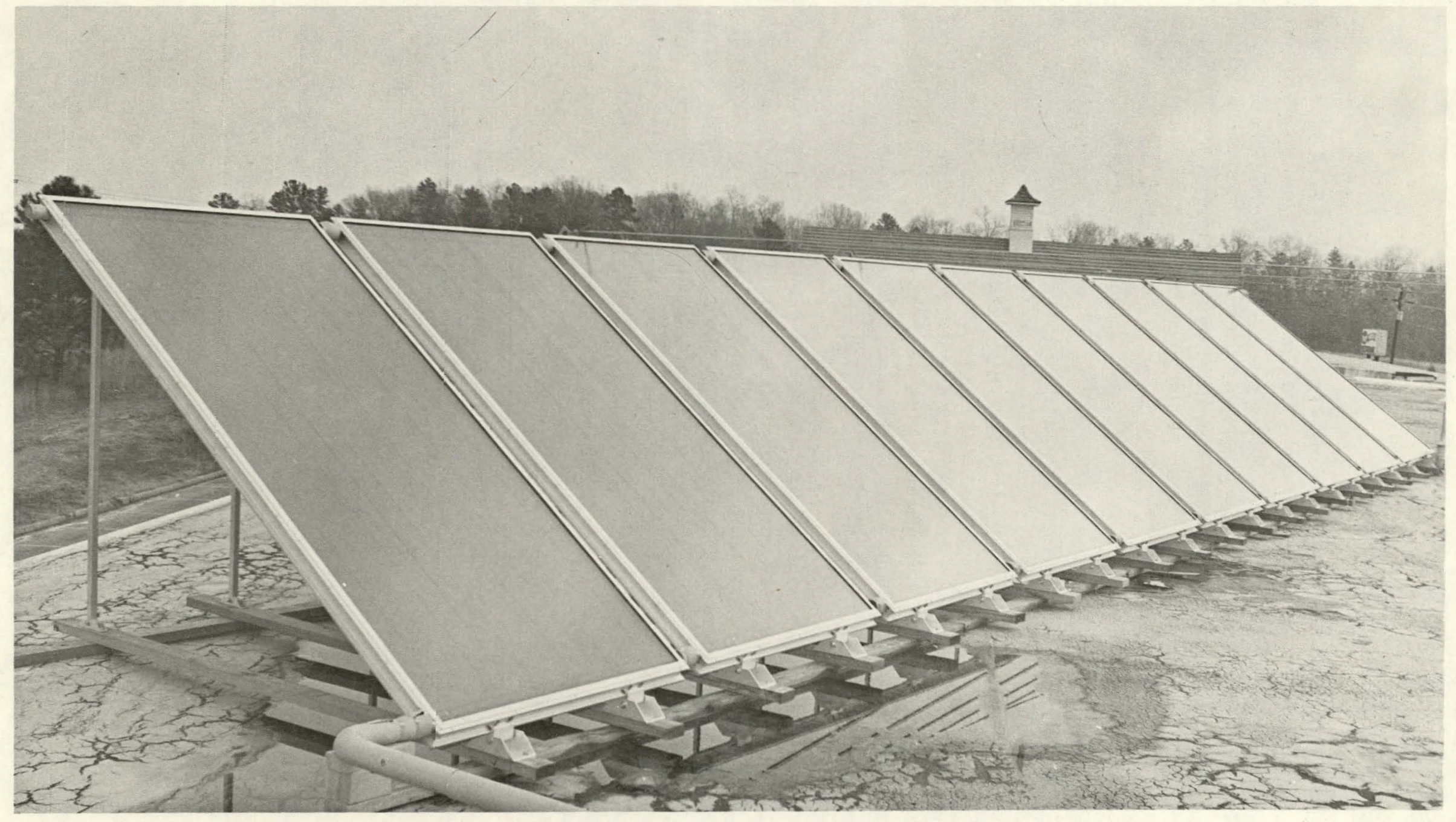

FINAL INSTALLATION 
Installation of this system was started on November 5, 1977. Complete system start-up and continuous operation was begun two weeks later. This system has performed flawlessly for one year. It is of note that the system encountered sub-zero temperatures on its fourth night of operation with no problems. Also in January, 1978, this system was subjected to $80 \mathrm{mph}$ winds. The ensuing storm destroyed a portion of the motel restaurant but did no damage to the solar system. Since funds were not provided for metering equipment, the actual system performance is not known, however, at the end of one year of operation, system performance will be evaluated based on previous year's occupancy records for the motel and pertinent weather data.

VI. PROBLEMS ENCOUNTERED AND SOLUTIONS

The only problem encountered thus far was a reroofing job which necessitated careful movement of the piping supports so as not to disturb the slope of the piping. This problem was very minor in nature and a conversation between the engineer and roofer solved it quickly.

Potable water has been an often-discussed subject when utilizing a single wall heat exchanger (as in this installation). This system utilizes no corrosion inhibitors and only municipal water as the heat transfer medium. However, there has been some question as to the potability of this water. In answer to this question, the designer submits that the water in this tank was tested by local health authorities and compared to tap water at the installation and no difference was found. It is this author's (M. Coley) opinion that unnecessary complications such as these are continuing to inhibit the growth of solar energy.

VII. SUCCESSFUL COMPONENTS

The success of each subsystem component of this installation is selfevident from the above mentioned performance record. This system has been subjected to marbles thrown by kids, wind storms, sub-zero temperaturcs, and roofing contractors and continues to perform with no maintenance thus far. 
APPENDIX A

SOLAR HOT WATER PLANT DRAWING

FOR

DAYS INN OF AMERICA, INC.

ANDERSON, SOUTH CAROLINA 


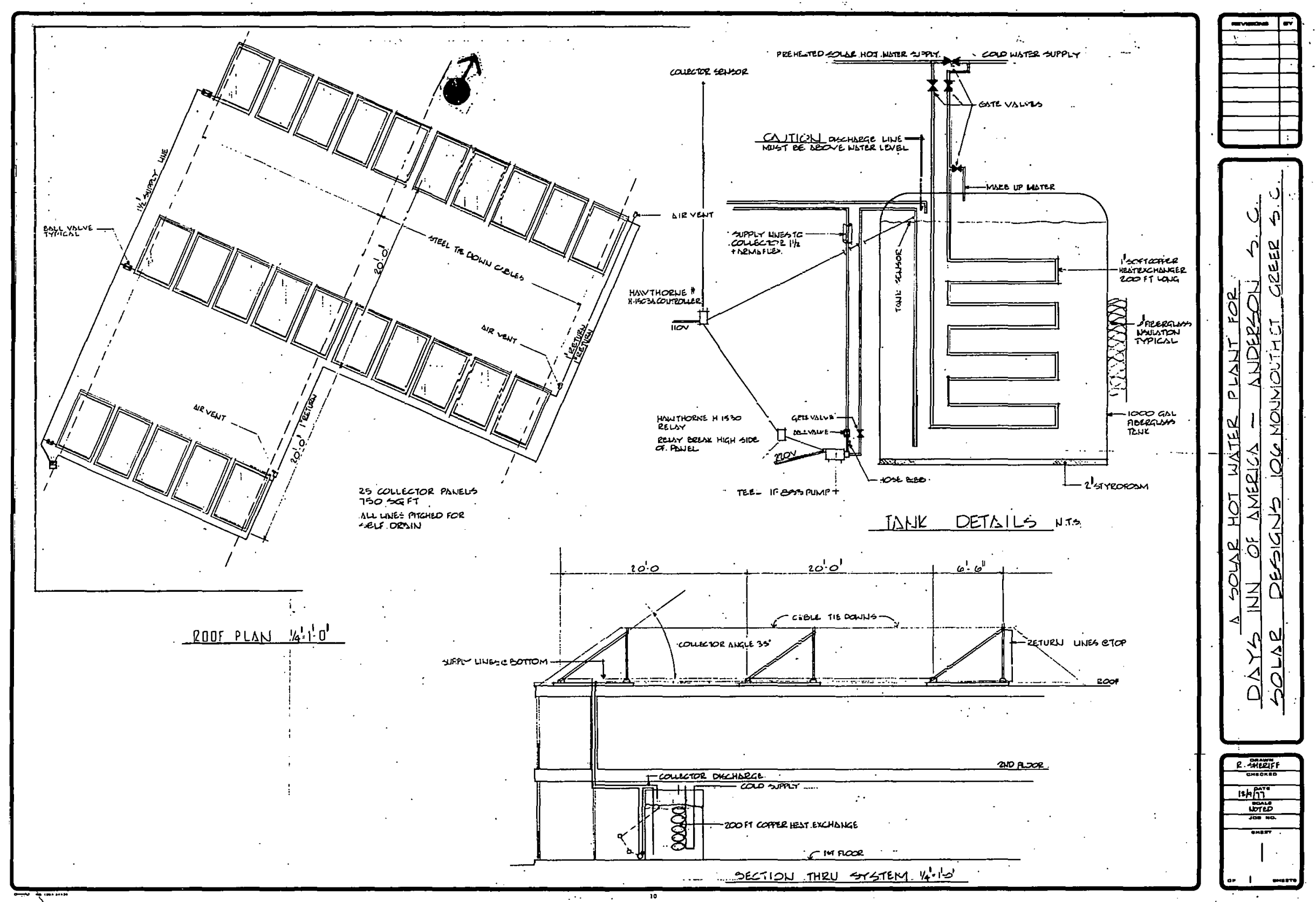




\section{APPENDIX B}

VERIFICATION AND ACCEPTANCE 


\section{SOLAR DESIGNS}

TAYLORS. SOUTH CAROLINA 29687

803.244.5207

RESIDENTIAL

- space heating

- solar hot Water heaterb
COMMERCIAL

- space heatime

- Service Hot Water

\section{VER IF ICATIONS}

1. Final Field Inspection Report, attached.

(a) was installed per as built drawings.

\section{Solar Designer}

(b) Met the acceptance test plan

The system was brought up to operating conditions within

the specified temperature and pressure conditions. All

sub components were then checked for performance. The system met all design criteria.

$+$

(c) Met the interim performance criteria

This is to certify that all solar work performed under Grant \# 77-G-01-1663 met the interim performance criteria requirements.

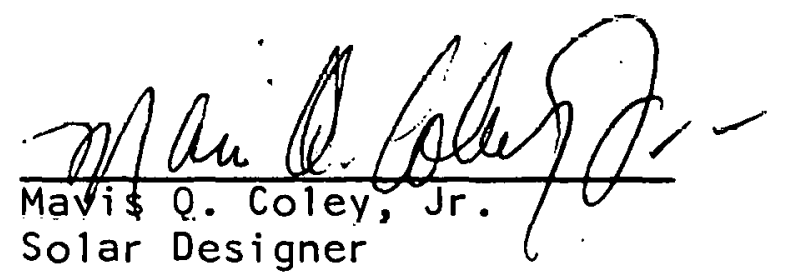




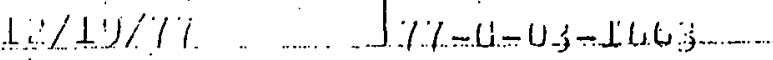
nisuecr $r$

PON-EG-77-N-03-1450

LOCATION

Anderson, South Carolina

SONTRACTOR of America, Inc. WeVTHER Q. Goley TEMF. 55 OAT 10 AN overcast

PRESENT A'T SITE

J.A. Grissett, Chip Carroll,

Barbara Baughman, Sydney Carter,

M. Q. Coley, R. A. Brown

THE FOLLOWING WAS NOTED

Contracting team consisting of Owner's representative, architect, engineer, and installer met for final inspection. One collector plate brace foot bolt was noted as missing and guy wire clamp for center collector array had not been installed. Installer corrected both items. The installation is complete as called for in plans.

The total system was described in detail to maintenance personnel.

Operation details including turning system on and off manually, identification of all supply return lines and valves, as well as temperature. and water levels, were discussed with the maintenance personnel.

The installation is considered as approved by architect and recommended to Owner for acceptance.

copies to Mavis Q. Coley, Jr. R.A. Brown, Sr.
FUNAL FIELD INSPECTION REPORT SIGNED 


\section{APPENDIX C}

OPERATOR'S INSTRUCTION

AND

MAINTENANCÉ MÁNUAL 
OPERATOR'S INSTRUCTION

AND

MAINTENANCE MANUAL

FOR: "OPEN" SYSTEM

SOLAR HOT WATER PLANT

PREPARED BY: MAVIS Q. COLEY SOLAR DESIGNS 4 ARDMORE DR. TAYLORS, S. C. 29687 803-244-5207 
TABLE OF CONTENTS

I General Discussion

II Specific System Components Discription and Function 19

II Maintenance Requirements $\quad \therefore 22$

IV Trouble Shooting Guide 23

V Warranty Information 24

VI Names, Addresses and Phone Numbers of Project Members 24 


\section{GENERAL DISCUSSION}

This solar system is, in effect, a hot water preheat system. Cold supply water is circulated through a copper coil heat exchanger submerged in a 1,000 gallon fiber glass tank. This water is heated by water that is heated by the solar system. The pre-heated cold supply water is then fed to the existing electric hot water heaters. If the solar system cannot supply the required temperature, then the electrical hot water heaters boost the temperature to the desired level.

An open solar system is one in which the heat transfer fluid is circulated at atmospheric pressure. This system is an open system. A closed system utilizes heat exchangers between the solar collection loop and the storage tank with inherently lower efficiency than the open system with no heat exchangers. The open system uses water as the heat transfer fluid. Water has the highest heat capacity, and lowest viscosity of any common materials. However, in an open system provisions must be made to drain the oollectors when freezing conditions exist in the collectors. Imphasis is placed here since weather conditions may $\therefore$ prevail where the ambient temperature may be below freezing, and the solar absorber plate is hot enough for effective solar heat collection. In this open system when the controller senses that energy can be collected, the pump starts and filis the collectors with water. The pump is self priming, because it is located below the water level in the storage tank. The pump runs until the collectors cool to within a few degrees of the storage tank' temperature. At this point the pump shuts down. . This system has been de-. signed to be self draining to prevent freeze damage 
to the collectors. The collector loop is supplied with three airvent valves to prevent fluid entrapment. Also, as a fail-safe measure the water level in the storage tank is maintained below the collector discharge line, allowing air to enter the system and allow drainlng to take place. 


\section{SPECIFIC SYSTEM COMFONENTS}

\section{DESCRIPTION AND FUNCTION}

Please refer to enclosed schematic for system component guide.

\section{COMPONENT}

(1) plate sensor

(2) collector

(3) ball valve

(4) ball valve

(5). gate valve

(6) controller

(7) tank sensor

(8) collector discharge line

(9) collector jick-up line

(10) storage tank

(II) heat exchanger

(12) gate valve

(13) gate valve

(14) gate valve

\section{FUNCTION}

To sense plate temperature.

To collect solar energy.

To regulate flow in each collector bank.

To regulate flow in main supply line to collectors. (Preset at $16 \mathrm{gal} / \mathrm{min}$ )

To isolate pump (17) when used with ball valve (4) if repairs are necessary.

Constantly compares plate sensor temperature (1) to tank sensor (7) and starts or stops pump (17) acting through relay (18).

To sense tank temperature.

To carry solar heated water from collector to top of storage tank.

To pick up cold water and transport it to collectors.

To store solar heater water and house load heat exchanger.

To heat the cold water in the supply line as it passes through the solar heated storage tank.

When valve (14) is closed and (12) and (13) is open cold supply is preheated by solar storage. When (12) and (13) is closed and (14) is open the solar system is isoliated and may be shutdown for repairs wtthout interruption of regular hot water service. 


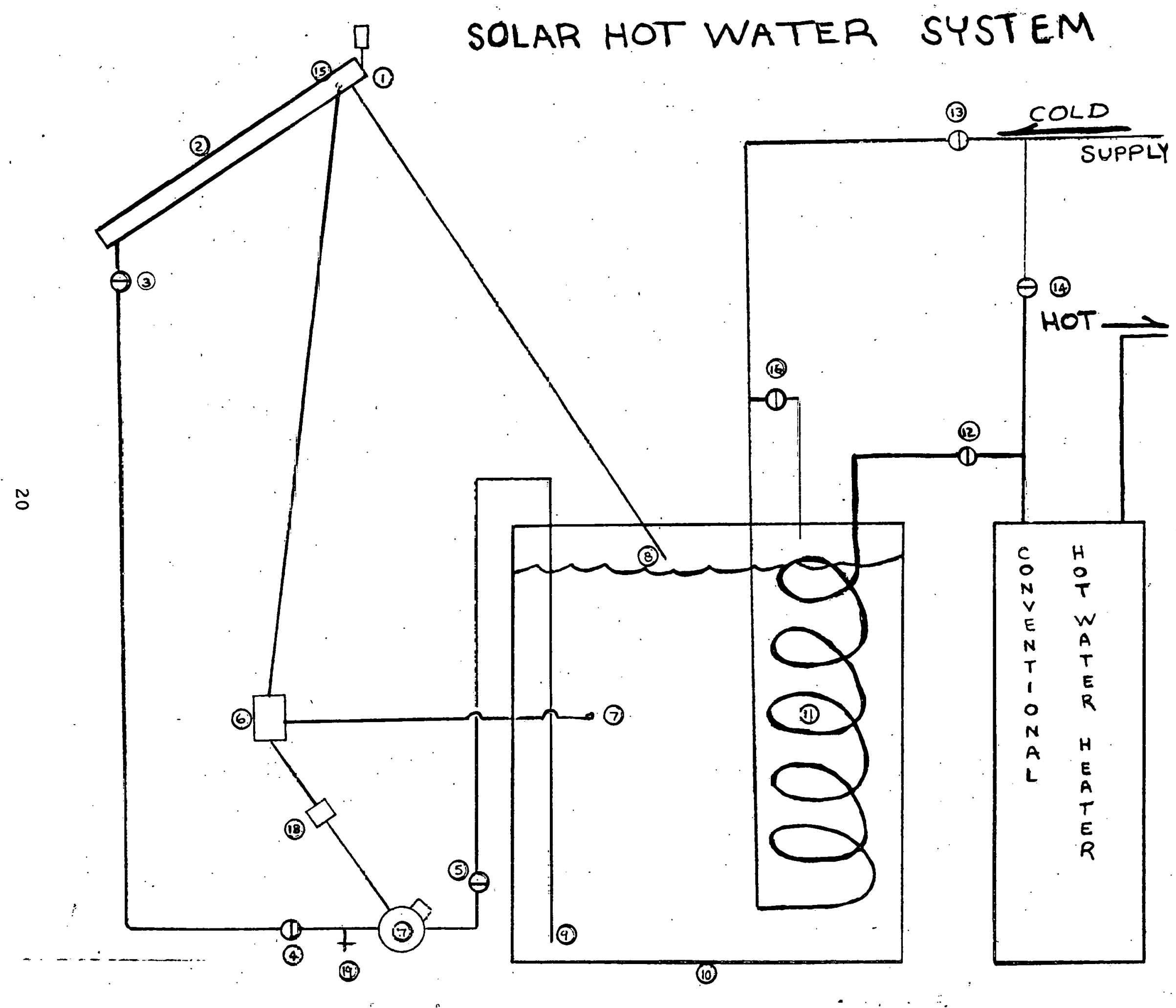


(15) air vent valve

(16) make up line

(17) pump

(18) relay

(19) hose connection
To allow air to escape from system when pump (17) starts, or to allow air to enter the system when pump (17) shuts down.

Allows water to be added to storage tank to compensate for evaporation.

Collector pump to transport water from storage to collectors.

Allows controller to control larger pump.

By closing ball valve (4) and opening hose connection, the tank may be pumped empty for cleaning, if necessary. 
MAINTENANCE REQUIREMENTS

(1) Once each month

a) Check water level in storage tank by opening manway on top of tank. If low, add water with make up line (16). CAUTION: NEVER ALLON WATER LEVEL TO COVER COLLECTOR DISCHARGE LINE. If this happens and air vente fail, system could freeze. Solar collectors are not guaranteed against freeze damage.

b) Periodically check that controller power light is on.

(2) Once each year

a) Check pump seals for leakage, replace if necessary.

b) Check collectors on roof for leaks. Tighten couplings, if necessary.

c) Check pH of water in storage tank, should be between 7 and 9.

This solar system has been designed for long and trouble free operation. Howerer, if trouble should occur, please refer to Trouble Shooting Guide in the next section. 
(1) Pump fails to start on obviously sunny day.

a) check controller power supply (red light should be on).

b) check controller fuse.

c) unplug relay from controller and plug it into $110 \mathrm{~V}$ power supply, if pump starts trouble is with controller.

d) if pump started in (c) above check controller as follows:

1) check sensor wires to make sure they are tight.

2) refer to enclosed information for further checks on controller and sensors.

(2) Pump fails to shut off at sundown.

a) unplug relay from controller. If pump continues to run, trouble is with relay.

b) if pump stops in (a) above, trouble is with controller or sensors.

(3) There are no other active parts to this solar system. Should trouble persist, consult Solar Designs. 
W ARRANTY INFORMATION

(1) Materials supplied by Georgia-Carolina Heating and Air Conditioning and workmanship are guaranteed for one year.

(2) Please refer to the enclosed (page 26) information on collector warranty.

(3) Please refer to the enclosed (page 29) information on controller warranty.

(4) Please refer to the enclosed (page 30) information on the tank warranty.

(5) Please refer to the enclosed (page 33) information on the pump warranty.

VI

SOLAR PLANT PROJECT MEMBERS

Mavis Q. Coley

Solar Designs

4 Ardmore Drive

Taylors, SC 29687:

(803) 244-5207

Sydney Carter, ALA

Planning Consultail

1296 Broad St.

Augusta, GA 30902

(404) $724-2443$

Bob Brown

Georgia-Carolina Heating and Air Conditioning

304 Clearwater Rd.

North Augusta, SC 29841

(803) 279-4915 
Solar Designs will perform the following service on a bi-annual basis:

(1) Visual inspection of all solar components.

(2) Repair of all leaks.

(3) Check $\mathrm{pH}$ of water and adjust to $7-9.5$ to provide maximum copper corrosion protection.

(4) Repair or replace controller, if it fails.

(5) Repair or replace pump, if it fails.

The above service starting on December 16, 1978 will be provided for a fee of $\$ 100.00$ per year. 
6291.7 th Avenue West • Bradenton, Florida $33505 \cdot(813) .748-3433$

GTC - LIMITED WARRANTY (Revised 10/10/77)

Gulf Thermal Corporation warrants its collectors to be manufactured to high standards of workmanship. Only first commercial grades of materials from reliable sources are used throughout. Each absorber plate is pressure tested prior to its installation into a finished unit.

For a period of five years from the date of installation, GTC will repaly or replace any defective parts where such defect is the result of manufacturing error including cost of labor, materials, installation and shipment to installation site within the Continental U.S. or to the appropriate U.S. port of embarkation for overseas sites.

This warranty goes with the collector and is unaffected by change of ownership as long as the collector remains in the original installation. Owners wishing to move collectors to a new site should contact the company for special warranty coverage.

Gulf Thermal collectors are not warranted against glass breakage, damage due to freezing or copper damage due to unacceptable transfer fluid. In open systems water having a ph between 9.487.0 is acceptable. In closed systems original fluid and any makeup fluid should consist of $50 / 50 \mathrm{mix}$ of Prestone II $(R$ manufactured by Union Caruide Corp. (or equivalent) and distilled water if available, otherwise water testing from 9.4 to 7.0 . ph.

The company's liability under this warranty shall be ended in the event of breakdown of the panel due to improper installation, reglazing, failure to replace broken glass promptly, or other breach of the enclosure allnwing the intrusion of excessive moisture or other foreign material.

In the event of breakdown due to corrosion of the copper flow cubes when transfer fluid has been acceptable as above defined, Gulf Thermal warrants for the first year after completion of installation all costs of parts and labor required to remedy the defect including replacement of the absorber plate if necessary. For the next four years Gulf Thermal will deliver to the site all parts needed to remedy the defect including a replacement absorber plate or entire new collector if necessary.

Consequential damages as result of failure of this collector are not warranted. 
1. This controller is not weatherproof and is not to be installed in any location exposed to external weather conditions.

2. Unit is fused with a 6 Amp. 3AG fuse. Frost control output is fused with a $4 \mathrm{Amp}$. 3AG fuse. Use of higher rated fuses will void warranty.

3. These controls contain no user serviceable components - - do not remove face plate.

4. Do not mount tank sensors by drilling through or into glass-lined water storage tank.

5. Although sensors are weatherproof, they are not designed to be immersed in water. Doing so may cause controller to malfunction. Use Model \# H-1526 immersion sensor when sensor immersion is desired.

6. Fixflo controls will control virtually any load up to 6 Amp., but variflo controls are to be used only with pumps, motors, and blowers which are speed controllable. Consult list on reverse side.

\section{INS'TALLATION}

Sensor Type

Standard Sensor

Immersion Sensor (optional)

$165^{\circ}$ Upper Limit (optional)

$150^{\circ}$ Upper Limit (optional)

$38^{\circ}$ Frost sensor (optional)
Model Nuriber

H-1525

H-1526

- $\mathrm{H}-1515$

$\mathrm{H}-1516$

H -1521
Lead Color

Black

Black

Red

Orange

Yellow

1. Using a sheet mctal screw, attach plate sensor (H-1525) to collector plate as near as possible to collector outlet (see Figure on reverse). Sensor may be climped to output tube using a hose clamp; but care must be taken not to crush the sensor "body". Alternately, Model H-1526 immersion sensor may be used.

2. (Optional) If draindown freeze protection is to be used, mount sensor (H-1521) on collector panel in contact with lowest tube. Any number of these sensors may be wired in parallel to provide simultaneous monitoring of several points.

3. Mount tank sensor $(H-1525)$ on storage tank near outlet to collector. On a standard electric hot water heater tank, slip the sensor tab beneath the lower thermostat mounting clip. Again, Model H-1526 immersion sensor may be used.

4. (Optional) Mount upper temperature limit sensor (H-1515 or $\mathrm{H}-1516)$ at top of storage tank (See Figure on reverse).

5. Run stranded twisted pair hookup wire (Type H-1550, II-1555 or equivalent) to controller from sensors. Make connections to sensors using crimp-type wire nuts (included) or by soldering and taping. 
6. Select clean, dry, oil-free surface to mount control. A filat non-porous surface is best. On damp, porous, and grainy surfaces, Model H-1535 mounting plate is reconmended. Peel release paper from back of control and press into position.

7. Attach sensor hookup leads to thejr rospective torminals as designated on the controller face plate. If upper limit sensing is to be used, remove jumper bridging those terminals. If stopped circulation upper limit protection is to be used, wire upper temperature limit sensor in series with plate sensor, and attach to plate sensor terminals.

8. Plug circulator into "controlled output" on face of controller. Plug auxiliary equipment into "frost control" output on face of control.

9. Check all sensor leads and electrical connections for proper installation.

10. Plug controller into any standard $117 \mathrm{~V} A C$ outlet.

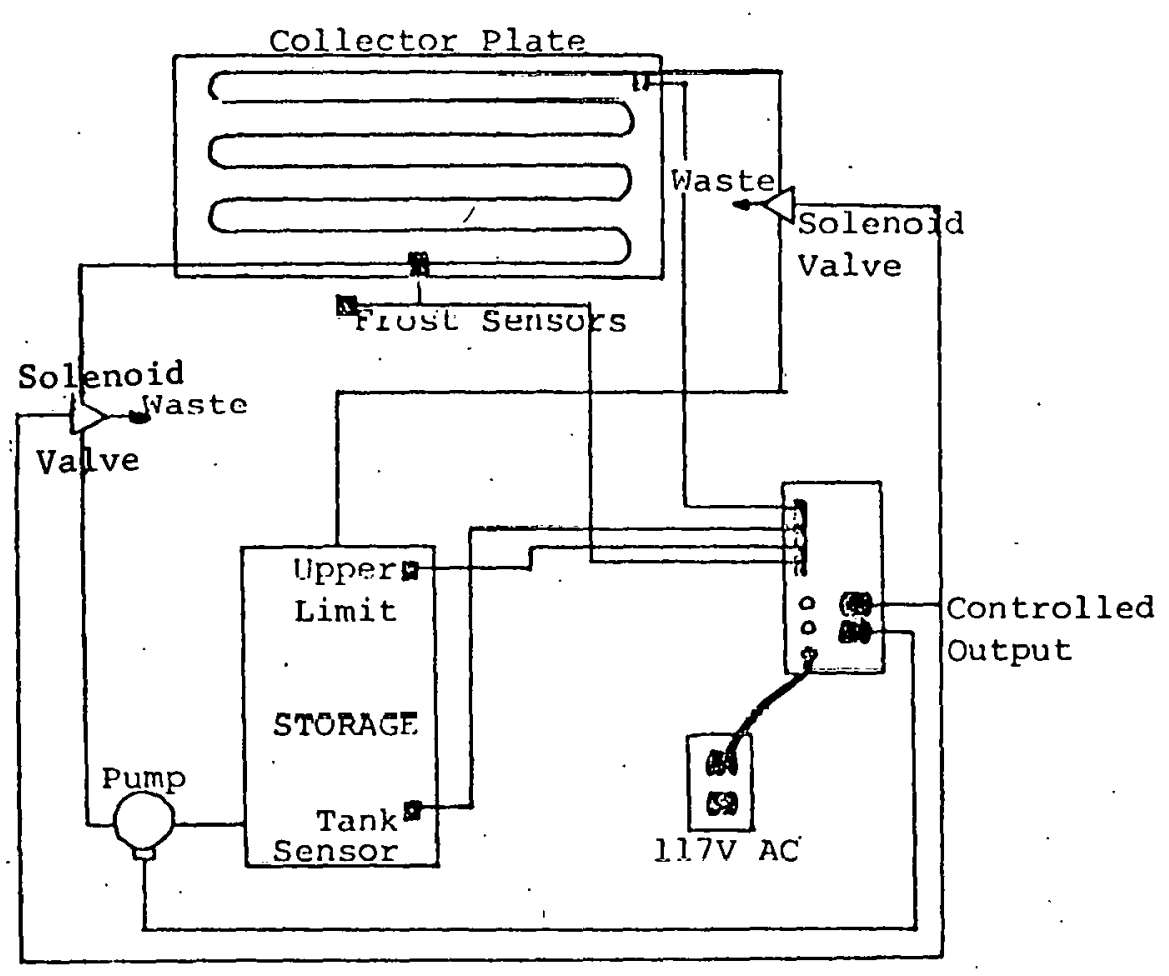

The figure at the left shows the location and wiring of sensors in typical installations using $\mathrm{H}-1504-\mathrm{A}$ and H-1511-A controllers.

RECONMENDED PUMPS AND BLOWERS

The following have been tested by Hawthorne and have been found to be compatible with variflo controls. Before attempting use of any unlisted. pump or blower with variflo controls, please consult Hawthorne. Use of incompatible equipment may result in damage to the equipment and to the con-. trol. as well as invalidation of warranty.

Pumps

Grund fos UPS 20-42 (1/20 H.P.)

Grundfos UP 25-42S (stainless steel) Grundfos UP 26-64 (1/12 H.P.)

Hartell] GPPS Series

March 809 (I/200 H.P.)

March 809-HS

March 821 (BR) (1/20 H.P.)

sundstrand LA43

Teel 1 P760 "(l/200 H.P.)

Teel 1P761 (1/20 H.P.)

Blowers

Lau Model DD9-9R

REPAIRS AND REPLACEMENT - Field repairs must not be made. Repairs or replacement of defective units may be obtained from your Hawthorne dealer where you purchased your control or by returning it to liawthorne Industries, shipping prepaid. Please enclose an explanation of the type problem encountered, as well as a sketch of the system in which it was installed, showing sensor locations. All repairs or replacements will be made in accordance with the provisions and conditions of the Manufacturer's Limited Warranty (enclosed). 


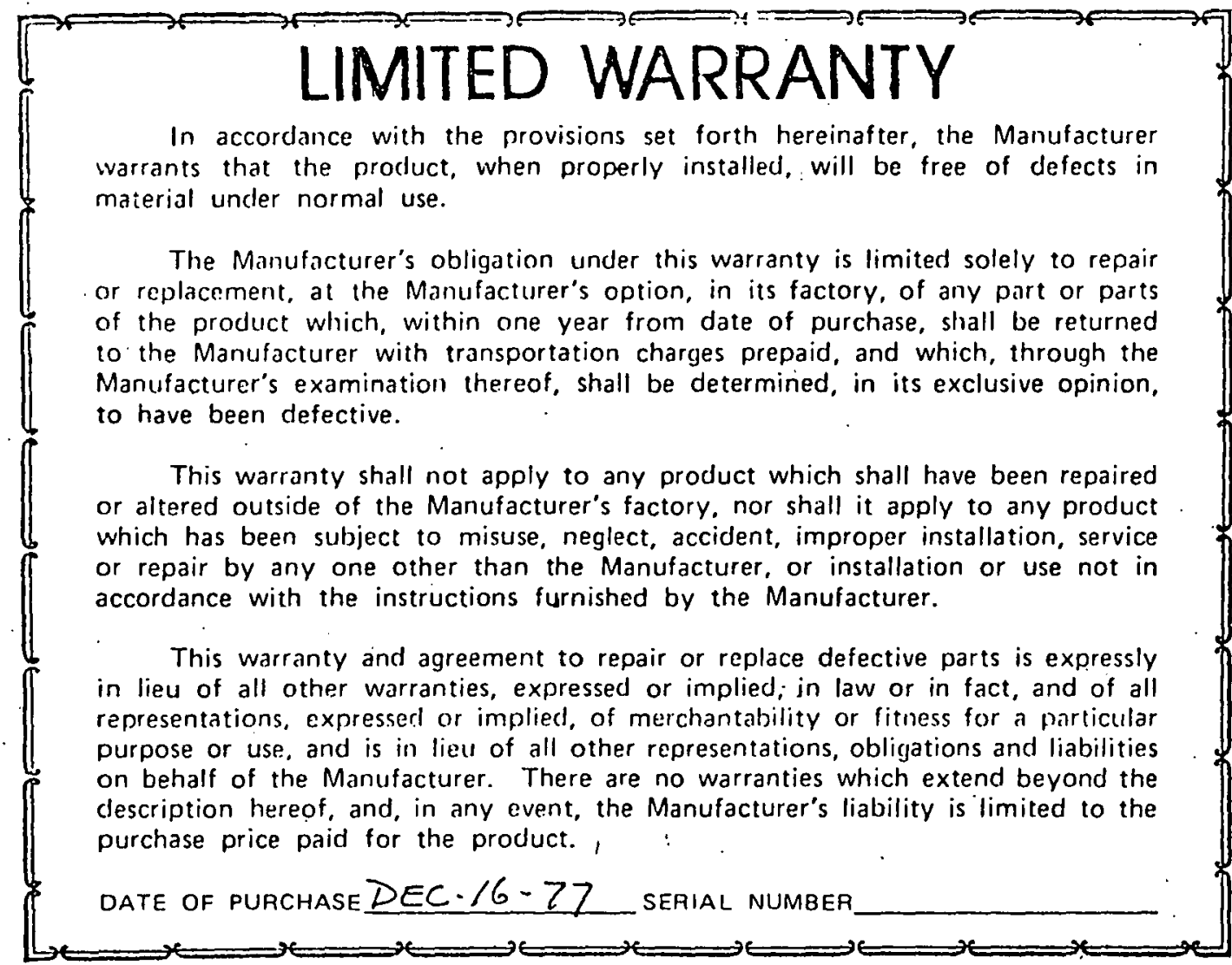

\section{WARRANTY REGISTRATION}

PURCHASED BY:

Owner's Name DAYS INN

Street HWY 187

Ciry ANDERSOIN State S.C. Zip

Date of Purchase DEC $-16-77$

SOLD BY:

Dealer's Name - SOLAR DESIGNS

Street 106 MONM MOUTH CT. RT-4

City GREER State S.C. Zip 29651

MODEL NUMBer $H-1504-A$ SERIAL NUMBer 


\author{
Storage Tank \\ BEIDEN:BAUGH PRODUCTS, I N C.
}

\title{
STANDARD CONTRAC'T TERMS AND CONDITIONS
}

The proposal of which these conditions are a part, is subject to the following Contract Terms and Conditions, and any order received referring to this proposal shall be cleemed to have incorporated these contract conditions. No sale shall result from this proposal until the order of the Buyer is received and accepted by Beden-Baugh Products, Inc., at its home office in Laurens, S. C.

NO CONTRACT TERM OR CONDITION SHALL BE AMENDED DELEIED OR $\triangle D D E D$ WITHOUT THE F.XPRESS WRITTEN CONSENT OF BEDEN-BAUGH PRO. DUCTS, INC.

\section{SCOPE OF WORK}

Beden-Baugh Products, Inc. will furnish labor, material, tools and equipment to fabricate the items to the designated drawings in its shop in I.aurens, S. C.

\section{PRICE}

(a) The contract price is based upon completing the work without overtime unless otherwise specifically provided for.

(b) Unless otherwise specifically provided, the price of the fabricated items is F. O. B., our plant, Laurens, S. C., at which time titje shall pass to the Buyer.

(c) Inless otherwise specifically provided, the Contract price does not include sales, use, excise or similar taxes, whether federal, state or local. The amount of any such tax as applicable to the work shall be paid by the Buyer in the same manner and with the same effect as if originally added to the purchase price.

(d) Any additional cost including a reasonable profit thereon incurred by Beden-Baugh Products, Inc, by reason of a change by the Buyer in the nature, scope or amount of work shall be paid by the Buyer as though it were originally added to the purchase price.

\section{COMPLETION DATE}

The completion date, where stated, is approximate and is subject to Buyer's furnishing of drawings or Buyer's approval of Beden-Baugh Products, Inc.'s drawings, and to delays due to acts of God, acts of the Buyer, war, riots, fires, explosions, floods, strikes, lockouts, injunctions, inability to obtain fuel, power, material, labor, containers or transportation facilities and any other action beyond Beden-Baugh Products, Inc.'s control.

\section{PAYMIENT}

Invoices shall be due in full 30 days net from date of shipment. If shipment is substantially dclayed by buyer after title passes, payment shall be due in full within 30 days from date title passes to buyer.

\section{IVARRANTY}

Beden-Baugh Products, Inc. warrants only that the items fabricated under this Contract will be free from defect in material and workmanship when exposed to the normal operating conditions as represented by the Buyer and as stated in the Contract proposal provided the proper assembly and installation procedure of the items have been followed. In the event of the failure of material or workmanship of the item as above provided, Beden-Baugh Products, Inc. agrees to replace or repair said item provided a written claim is re. ceived by it within one (1) year from the dale of shipment of said item to the Buyer. No material shall be returned to Beden-Baugh Products, Inc. without its prior written consent. Maximum liability under this Warranty is limited to BedenBaugh Products, Inc.'s cost of replacing the defective item in its plant at straight time rate. If the Buyer desires a defect to be.corrected under this Warranty at - place other than Beden-Baugh Products, Inc.'s plants, the Buyer shall pay all costs in excess of those incurred in the plant at straight lime rate. In no event ehall Beden-Biugh Products, Inc. be responsible for consèquential damages of any such defective material, or workmanship including, but not limited to, the Buyer's loss of material or profits, increased expense of operation, down-time or reconstruction of the work and in no event shall Beden-Baugh Products, Inc. 's obligation under this Warranty exceed the original Contract price of the defective iten.

THIS WARRANTY IS IN LIEU OF ANY OTIER WARIRANTY OR OBLIGATION, EXPRESS OR INIPLIED $\overline{\Lambda N D ~ N O}$ LIABILITY IS $\Lambda$ SSUMIED BY BRDEN-BAUGH PRODUCIS, INC: EXCEPT AS IS EXPRESSLY STATED ABOVE.

\section{DESIGNS}

Any designs suggested or offered by Beclen-Baugh Products, Inc. will be matle as a service to assist buyer and will be based on information furnished by buyer. The furnishing of published or special design and installation information or field supervision is not an approval or an acceptance of buycr's designs or a guarantee of porformance by Beden-Baugh Products, Inc., and will not be relied upon as such by buyer.

\section{INSPECTION}

Arrangements can be made with Beden-Baugh Products, Inc. for in-process or final inspection within our plant. Customers are requested to arrange scheduling of inspections so as to minimize disruption of Beden-Baugh's production activities.

\section{CANCELLATION}

Buyer may cancel this agrcement only,upon payment of rcasonable Cancellation charges which shall take into account expenses incurred and commitments made by BedenBaugh Products, Inc.

\section{SETTLEMENT OF DISPUTES}

Any dispute arising under this contract which cannot be settled by Beden-Baugh Products, Inc., and buyer will be resolved by submission of the dispute to final and binding arbitration under the rules and regulations of the American Arbitration $\Lambda$ ssociation for voluntary arbitration of commercial contract disputes: 


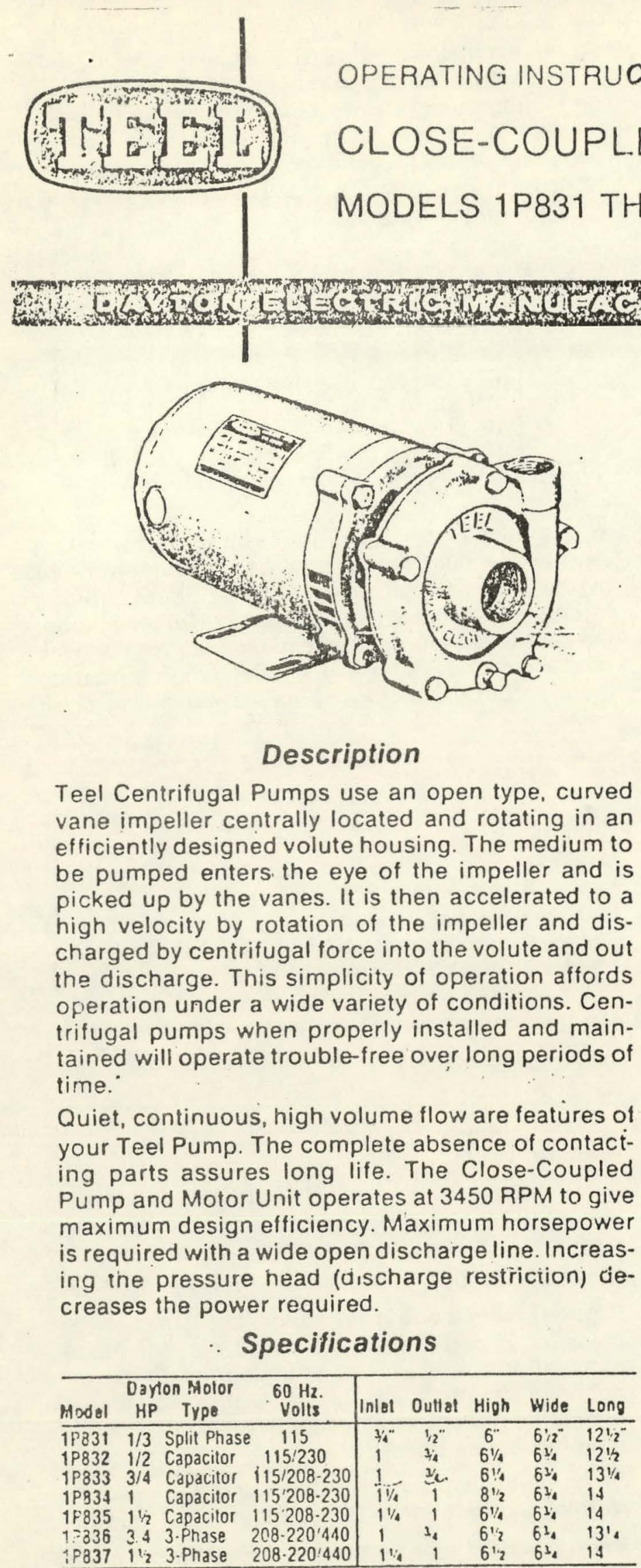

Performance

\begin{tabular}{l|ccccccccc}
\hline Modsi & \multicolumn{10}{|c}{ PUMP HEAD IN FEET } & & \\
& 5 & 10 & 15 & 20 & 30 & 40 & 50 & 60 & 70 \\
\hline 11331 & 29 & 26 & 25 & 23 & 17 & 12 & 2 & - & - \\
1 P332 & 43 & 37 & 32 & 28 & 20 & 2 & - & - & - \\
$1 P 833$ & 83 & 78 & 75 & 68 & 57 & 47 & 22 & 1 & - \\
$1 P 334$ & 89 & 86 & 83 & 76 & 67 & 54 & 37 & 10 & - \\
$1 P 335$ & 95 & 94 & 92 & 88 & 77 & 66 & 52 & 32 & - \\
$1 P 836$ & 83 & 78 & 75 & 68 & 57 & 47 & 22 & 1 & - \\
$1 P 837$ & 95 & 94 & 92 & 88 & 77 & 66 & 52 & 32 & - \\
\hline
\end{tabular}

Safety

When wiring motor, follow all local electrical and safety codes, as well as the National Electrical Code (NEC) and the Occupational Safety and Health Act (OSHA).

Motor must be securely and adequately grounded. This can be accomplished by wiring with a grounded, metal-clad raceway system, by using a separate ground wire connected to the bare metal of the motor frame, or other suitable means.

- Always disconnect power source before working on or near a motor or its connected load. If the power disconnect point is out-of-sight, lock it in the open position and tag to prevent unexpected application of power.

Be careful when touching the exterior of an operating motor - it may be hot enough to be painful or cause injury. With modern motors this condition is normal if operated at rated load and voltage - modern motors are built to operate at higher temperatures.

Do not insert any object into motor.

\section{Thermal Protection}

Motor is equipped with an automatic reset thermal protector, and may restart unexpectedly when motor and protector cools after tripping. Protector tripping is an indication of motor overloading as a result of operating the purip dit iow heads (low discharge restriction), excessively high or low voltage, inadequate wiring, incorrect motor connection, or a defective motor or pump.

\section{Installation}

Improper installation may cause poor pump efficiency, increase power consumption and decrease operating life. Position your pump as close as possible to the source of liquid. Keep the suction line as short and direct as possible. Plan and installi, the suction line so that air pockets cannot form in it. Use a minimum of elbows and fittings and use a length of straight pipe at least 6 "long for the entrance into the pump suction. Never use pipe smaller than the pump port sizes and preferably use the next larger size. A suitable strainer should be installed in the suction line. The nel'arrea of the strainer must be at least four (4) times that of the suction pipe. 


\section{Location}

Locate pump close to and below the liquid level supply so that there will always be a positive supply of fluid at the pump inlet. If necessity demands that the pump be located above the liquid level, a positive sealing foot valve or check valve must be installed in the suction line below the liquid level.

Open, dripproof motors are designed to be used in clean. dry location with access to an adequate supply of cooling air. Ambient temperature around the motor should not exceed $104^{\circ} \mathrm{F}\left(40^{\circ} \mathrm{C}\right)$. For outdoor installations, motor must be protected by a cover that does not block air flow to and around the motor. For hazardous locations (explosive atmosphere), an explosion-proof motor may be required; consult your local governmental inspection agency for guidance.

\section{Suction}

Proper suction is the most important part of your pump installation. Most centrifugal pump problems can be traced to improper suction conditions. Flooded suction conditions have been outlined above. On a suction lift installation, install a foot valve at least 3 feet below the liquid level. Make sure there are no air leaks in this line. Suction lifts of more than 15 feet should be avoided.

\section{Power}

Voltage, frequency and phase of power supply must he that shown on the motor nameplate. On three phase systems, voltage on all three lines must be balanced. Unbalance greater than a 2 volt variation line-to-line can result in reduced torque, increased heating and noise, and premature motor failure. Low voltage can reduce performance and cause overheating.

Motor current may exceed rated value because of overloading or high voltage. Voltage $5 \%$ or more above rated will cause both no load and full load current to increase, frequently above nameplate value.

\section{Wiring}

All wiring and electrical connections must comply with the National Electrical Code (NEC) and local electrical codes. In particular, refer to Article 430 , "Motors, Motor Circuits and Controllers," of the NEC.

Use of a motor starter, either manual or magentic, incorporating thermal protection, is advisable and may be required by local electrical codes. Follow motor starter manufacturer's recommendations on thermal overload relay heater selection. Do not oversize heaters. On three phase systems, three heaters must be used.

Wherever possible, each motor should be powered from a separate branch circuit of adequate capacity to keep voltage drop, during starting and running, to a minimum. Increase wire size where the motor is located a distance from the power source.
Where extension cords are used, they should be as short as possible, for minimum voltage drop. Long or inadequately sized cords, especially on hard starting loads, can cause motor failure. Always use grounding-type ( 3 conductor) extension cords in conjunction with a properly connected, grounding-type receptacle.

MINISUM WIRE SIZES FOR WIHING AND EXTENSION CORDS

\begin{tabular}{|c|c|c|c|c|c|c|c|c|c|c|}
\hline \multirow{2}{*}{$\begin{array}{c}\text { MOTOA } \\
\text { HP }\end{array}$} & \multicolumn{2}{|c|}{$25 \mathrm{FT}$. } & \multicolumn{2}{|c|}{$50 \mathrm{Ft}$. } & \multicolumn{2}{|c|}{$100 \mathrm{Ft}$. } & \multicolumn{2}{|c|}{$150 \mathrm{Ft}$. } & \multicolumn{2}{|c|}{$200 \mathrm{Ft}$. } \\
\hline & $115 \mathrm{y}$ & $230 \mathrm{~V}$ & $115 V$ & $230 \mathrm{~V}$ & $115 \mathrm{~V}$ & $230 \mathrm{~V}$ & 115 & $230 \mathrm{~V}$ & 115 & $230 \mathrm{~V}$ \\
\hline $1 / 3$ & 14 & $18^{\circ}$ & 12 & $18^{\circ}$ & 10 & $16^{*}$ & 8 & 14 & & 12 \\
\hline $1 / 2$ & 14 & $16^{\circ}$ & 12 & $16^{\circ}$ & 8 & 14 & 6 & 12 & 6 & 12 \\
\hline $3 / 4$ & 12 & $16^{\circ}$ & 10 & $16^{\circ}$ & 8 & 14 & 6 & 12 & 4 & 10 \\
\hline 1 & 12 & $16^{\circ}$ & 10 & 14 & 6 & 12 & 4 & 10 & 4 & 10 \\
\hline $11 / 2$ & 10 & 14 & 8 & 14 & 6 & 12 & 4 & 10 & 2 & 8 \\
\hline
\end{tabular}

To connect motor for proper voltage, refer to the connection diagram located on the nameplate or inside the terminal box. On three phase motors, interchange any two line leads to reverse rotation. On centrifugal pump applications involving a three phase motor with threaded shaft, mutor rotation must be counterclockwise as viewed facing shaft end.

\section{Operation}

\section{Priming}

Your centrifugal pump must be satisfactorily primed before it will pump. Satisfactory priming requires that all air must be removed from the pump and suction lines and that these areas be completely filled with liquid. This must be accomplished with the pump at a standstill. A priming cup installed in the discharge line just above the pump is recommended.

\section{Maintenance}

\section{Routine:}

Pump should be drained if subjected to freezing temperatures. A drain plug is provided on the pump casing.

Clean the suction line strainer at regular intervals.

Properly selected and installed electric motors are capable of operating for years with minimal maintenance. Periodically clean dirt accumulations from open-type motors, especially in and around vent openings, preferably by vacuuming (avoids imbedding dirt in windings).

Pump motor is provided with sealed ball bearings. Normal relubrication of the bearings is not required.

Periodically check that electrical connections are tight.

\section{Mechanlcal Seal}

All Teel pumps are furnished with a precision mechanical seal. This seal is installed and checked at the factory and should require no adjustment at the time of the installation of the pump. Running the pump without water will result in rapid seal failure. 


\section{Maintenance (Cont.)}

After the pump has been in service for a long period of time, or if the pump has seen severe service on abrasive materials, it may be necessary to replace this seal (the seal may leak). Leakage can be detected by a dripping or flow of liquid from the area around the motor shaft.

The following instructions cover the removal and replacement of the mechanical seal:

CAUTION: The precision lapped faces on the mechanical seal are easily damaged. Handle your replacement seal carefully and read these instructions before attempting to replace the seal.

\section{Remoyal of Old Seal}

1. Disassemble the centrifugal housing (Ref. 8) from the pump by removing five (5) hex head capscrews (Ref. 11).

2. Unscrew the impeller (Ref. 7). A screwdriver slot is provided in the rear end of the motor shaft (remove bearing cap for access). To hold the shaft from turning, insert a large screwdriver blade into the slot. Thread is standard right hand. Turn the impeller counterclockwise to remove.

3. Grasp the ceramic seal seat (Ref. 5) and slip from the motor shaft.

4. Remove the pump body (Ref. 3) from the motor by removing four (4) hex head capscrews (Ref. 4).

5. Remove the spring seal (Ref. 5) by pushing from

HOW TO ORDER REPLACEMENT PARTS

Please provide following information:

- Model Number

- Serial Number (if any)

- Part Description and Number

as shown in Parts List.

Address order to:

Dayton Electric Aig. Co.

CUSTOMER SERVICE DEPT.

5959 W. Howard St.

Chicago, Illinois 60648 the direction of the pump body mounting flange (Ref. 3). Care must be exercised with pusher so as not to damage the seal cavity area.

\section{Installation of Replacement Seal}

1. Clean the centrifugal body seal cavity before inserting a new seal.

2. Using a clean cloth wipe the shaft and make sure that it is perfectly clean.

If removed, slide the rubber shaft slinger washer (Ref. 2) on the shaft until it is located about $1 / 8$ " from the face of the motor bearing hub.

3. Carefully wipe the surface of the ceramic seat with a clean cloth.

4. Wet the rubber portion of the ceramic seat with a light coating of oil, bore only.

5. Press the brass cap, bellows, and spring squarely into the cavity in the casing cover. Do not distort the brass cap. Press uniformly araund its flange.

6. After the seal is in place, insure that it is clean and has not been scratched or cracked.

7. Mount the centrifugal body (Ref. 3 ) on the motor mounting face. Carefully guide motor shaft through seal.

8. Apply a light coating of oil on the motor shaft. Slide the seal seat onto the shaft (with the sealing face first). Use a $5 / \mathrm{g}^{\prime \prime}$ I.D. tube, or $1 / 2^{\prime \prime}$ drive socket to aid in pushing the rubber portion on to the shaft.

\section{WARRANTY}

Teel Centrifugal Pumps are warranted against defects in workmanship or materials, under normal use (rental excluded) for one year from date of purchase.

Liability in all events is limited to the purchase price paid and liability under the aforesaid warranty is limited to replacing or repairing any part or parts which are defective in material or workmanship and returned to our Factory or Authorized Service Station, shipping cost prepaid. No warranty, expressed or implied, other than the aforesaid is made or authorized by Dayton Electric Mig. Co

PROMPT DISPOSITION will be made it item proves to be defective, within warranty. Before returning any item, write or call Dayton Electric Mig. Co. or dealer from whom product was purchased, giving date and number of original invoice. and describe nature of defect. If damage was incurred during transit to you, file claim with carrier.

DAYTON ELECTRIC MFG. CO., 5959 W. HOWARD STREET, CHICAGO, ILLINOIS 60648 


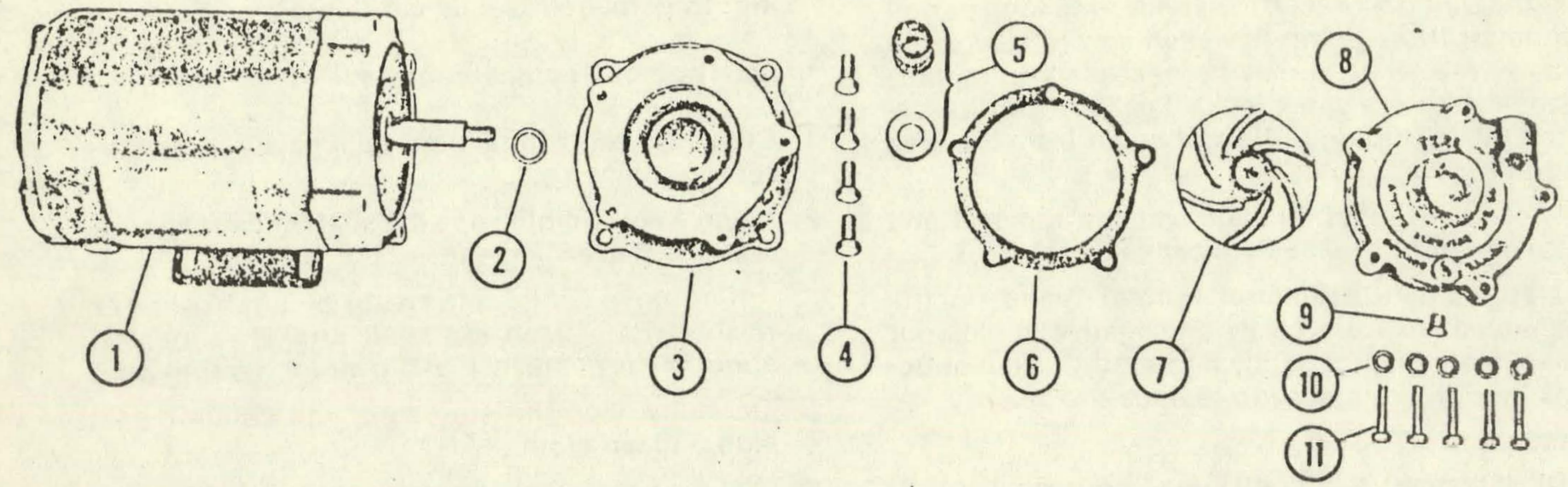

\begin{tabular}{|c|c|c|c|c|c|c|c|c|c|}
\hline $\begin{array}{l}\text { Ref. } \\
\text { No. }\end{array}$ & Description & $\begin{array}{l}\text { Qty. } \\
\text { Req'd. }\end{array}$ & $1 \mathrm{P} 831$ & 1P832 & $\begin{array}{l}\text { Part Nu } \\
1 \text { P833 }\end{array}$ & $\begin{array}{l}\text { nber For } \\
\text { 1P834 }\end{array}$ & $\begin{array}{l}\text { Model } \\
\text { 1P835 }\end{array}$ & 1P836 & 1P837 \\
\hline 1 & Motor & 1 & $8 K 492$ & $6 K 497$ & $6 K 507$ & $6 \mathrm{~K} 511$ & $5 K 687$ & 3 N088 & 3 NO9O \\
\hline 2 & $\begin{array}{l}\text { Slinger } \\
\text { Centrifugal Body }\end{array}$ & 1 & 6150 & 6150 & 6150 & 6150 & 6150 & 6150 & 6150 \\
\hline $\begin{array}{l}3 \\
4\end{array}$ & $\begin{array}{l}\text { Centrifugal Body } \\
3 / 8-16 \times 3 / 4^{\prime \prime} \text { Long Hex Head Bolt }\end{array}$ & 1 & 11968 & 11969 & 11969 & 11969 & 11969 & 11969 & 11969 \\
\hline $\begin{array}{l}4 \\
5\end{array}$ & & 4 & $\left({ }^{*}\right)$ & (*) & $\left({ }^{*}\right)$ & (") & (") & (") & ()$\left.^{\circ}\right)$ \\
\hline 6 & Gasket & 1 & 12315 & 12315 & 12315 & 12315 & 12315 & 12315 & 12315 \\
\hline 7 & Impeller & 1 & 11616 & 11618 & 116.18 & 11618 & 11618 & 11618 & 11618 \\
\hline 8 & Centrifugal Housing & 1 & 11970 & 11971 & 11972 & 11973 & 11974 & 11972 & 11974 \\
\hline 9 & $1 / 8^{\prime \prime}$ Cast Iron Pipe Plug & 1 & 11965 & 11966 & 11966 & 11967 & 11967 & 11966 & 11967 \\
\hline 10 & 1/4" Light Lockwasher & 5 & (6) & ( & (") & (") & $\left({ }^{*}\right)$ & (*) & (") \\
\hline 10 & 5/16. Light Lockwasher & 5 & - & (०) & $\overline{10}$ & $\overline{-1}$ & $\overline{1}$ & - & - \\
\hline 11 & $1 / 4-20 \times 1-1 / 4$ " Long Hex Head Bolt & 5 & (*) & 11 & 1 & (2) & (") & (*) & ()$\left.^{*}\right)$ \\
\hline 11 & 5/16-18 $\times 1-1 / 4 "$ Long Hex Head Bolt & 5 & & (*) & $\left({ }^{*}\right)$ & $\overline{-}$ & - & $\overline{0}$ & - \\
\hline 11 & 5/16-18 x 1-3/4" Long Hex Head Bolt & 5 & - & & - & (") & $\overline{(*)}$ & ( ) & $\overline{10}$ \\
\hline
\end{tabular}

(*) Standard hardware items available locally.

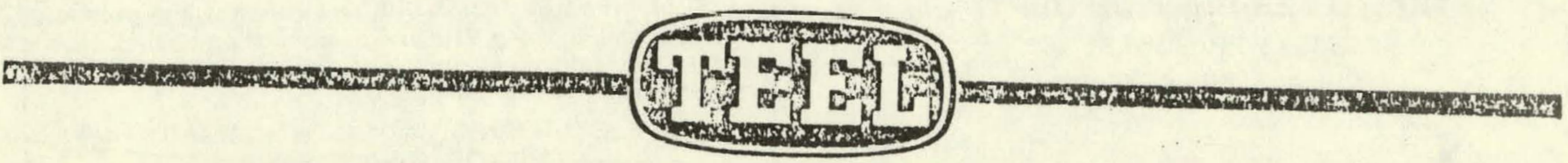

\$U.S. GOVERNMENT PRINTING OFFICE 1979-640-081/379 REGION NO. 4 